\title{
Cancer Prevention and Worksite Health Promotion: Time to Join Forces
}

Cancer Prevention in the Workplace Writing Group

Suggested citation for this article: Cancer Prevention in the Workplace Writing Group. Cancer Prevention and Worksite Health Promotion: Time to Join Forces. Prev Chronic Dis 2014;11:140127. DOI:

http://dx.doi.org/10.5888/pcd11.140127 㳙.

\section{Introduction}

The workplace is recognized as a setting that can profoundly influence workers' health and well-being $(1,2)$. The Centers for Disease Control and Prevention (CDC) workplace health promotion efforts address cancer prevention by focusing on cancer screening programs, community-clinical linkages, and cancer risk factors (eg, tobacco use, physical inactivity) that also influence risk for other chronic diseases (http://www.cdc.gov/workplacehealthpromotion/). Some efforts focus specifically on cancer; some focus on general chronic disease prevention. Additionally, the National Institute for Occupational Safety and Health (NIOSH), part of CDC, provides research and recommendations to address workplace hazards posed by chemicals that may increase cancer risk (http://www.cdc.gov/niosh/topics/cancer/policy.html).

Existing resources can be leveraged to expand the scope of workplace initiatives to address additional cancer risk factors and disparities. Changes to the physical and social characteristics of work environments are likely to have greater impact than health education alone (3). Given the aging US population (which is expected to result in a marked increase in the number of cancer diagnoses over the coming decades) and the prevalence of numerous risk factors among working-aged adults $(4,5)$, a multifaceted approach to cancer prevention in the workplace is timely and needed. In addition, community-based prevention efforts may offer unrealized opportunities to reach vulnerable working populations who are not served by workplace health promotion programs. In this essay, we draw attention to a wide variety of available $\mathrm{CDC}$ resources and provide ideas for new efforts to advance primary cancer prevention among working adults.

\section{Factors Related to Cancer Risk}

Many cancer risk factors could be influenced through efforts targeting the work environment, including facilities, services, and policies. Table 1 shows examples of risk and protective factors that may be amenable to workplace interventions. Some examples are specific to the work environment, such as exposure to known carcinogens (eg, diesel exhaust), higher levels of which are often permitted in the workplace compared with the general environment. Others are behaviors (eg, tobacco use) or chronic conditions (eg, obesity) that may increase cancer risk. The table also provides examples of protective factors (eg, staying physically active) that may reduce cancer risk. These factors affect a high percentage of US workers, so even small changes could have a large impact at the population level. Many of the examples are also related to other health outcomes, and the benefits of addressing them would extend well beyond cancer prevention.

\section{Integrating Health Protection and Health Promotion}

Traditionally, workplace health promotion programs have focused on health-related behaviors (eg, tobacco use cessation), while health protection programs have focused on addressing safety and health risks and hazard mitigation. New research provides evidence that integrating these 2 approaches may enhance program effectiveness to improve employee health, safety, and well-being (2). As discussed in the National Prevention Strategy

(http://www.surgeongeneral.gov/initiatives/prevention/strategy/), efforts to ensure worker safety on the job while also providing a work environment that supports healthy behaviors can create a culture in which worker health is viewed as a priority and healthy behaviors are more likely to be adopted by employees. NIOSH conducts research and 
develops programs to advance this integrated approach through the Total Worker Health program

(http://www.cdc.gov/niosh/twh).

Because many cancers share risk factors with other diseases and chronic conditions, cancer prevention efforts in the workplace may also be enhanced by coordination with initiatives to address other diseases and chronic conditions. For example, the role of obesity as a risk factor for cancer and type 2 diabetes has been explored in occupational settings (33). This integrated and comprehensive approach maximizes program success and potential for sustainability over time.

\section{Linking With Community Resources}

Given the "spillover" that often occurs between work and family lives $(2,34)$, a systems approach addressing the interrelationship between work, family, and community can maximize benefits. For example, employers can partner with organizations in the surrounding community to offer health-related programs and services to employees that complement workplace interventions

(http://www.cdc.gov/workplacehealthpromotion/assessment/assessment_interviews/index.html\#5). These linkages can extend support to employees when outside the workplace and provide services that are beyond the capacity or expertise of the employer (eg, partnering with local fitness facilities to provide discounted memberships to employees, promoting local farmers markets for access to fresh produce) (35).

Public-private partnerships may also contribute to effectiveness by bringing specialized skills and resources to an intervention (36). Community linkages are particularly important for small and mid-sized employers for whom a lack of resources can be a barrier to implementation and sustainability.

\section{Disparities Across the Workforce}

Differences across industries, workplace settings, and types of work create challenges to reaching certain groups and can contribute to cancer health disparities. For example, certain jobs expose workers to chemical and physical hazards (eg, second-hand smoke, excessive sun exposure) or require nonstandard work hours (eg, night shift work) that can contribute to an increased cancer risk (34). Furthermore, not all occupations are found in centralized work locations. Those working outside the typical office setting or without permanent worksites (eg, transportation and construction workers) may benefit from programs that are tailored to their work circumstances and link to other community resources. Additionally, telecommuting has become common among workers, and although the flexibility to telecommute may lend certain benefits, it may also create barriers to reaching employees through traditional worksite wellness programs $(34,37)$.

Health disparities among low-wage and low-income (LW/LI) workers are particularly concerning, as these workers may lack certain protections and worksite benefits available to higher-earning workers and be ineligible for government antipoverty supports (38). Temporary contract workers, seasonal workers, and part-time workers earning low wages tend to face worse working conditions and receive fewer benefits than workers in more permanent positions (34). Women and racial/ethnic minorities are overrepresented among LW/LI workers, further exacerbating health disparities among these groups (34). Health promotion and protection efforts targeting LW/LI workers may help reduce disparities. Such efforts will require buy-in from employers and managers, and potential benefits to employers (eg, reductions in absenteeism) should be highlighted.

Almost half of cancer survivors, individuals who have been given a cancer diagnosis at some point in their lives, are of traditional working age (ie, 18-64 years) (http://cancercontrol.cancer.gov/ocs/prevalence/prevalence.html\#age).

Although the unique needs of cancer survivors are outside of the scope of this essay, workplace prevention efforts may also reduce the risk of second primary cancers or cancer recurrence among cancer survivors.

\section{CDC-Supported Program Activities}

CDC's National Comprehensive Cancer Control (CCC) Program supports states, tribes, and territories to establish coalitions, assess the burden of cancer, determine priorities, and develop and implement cancer plans

(http://www.cdc.gov/cancer/ncccp/). A scan of activities conducted by CCC programs indicated that only 15 (22\%) of 69 programs are engaged in efforts to promote primary cancer prevention in the workplace (J. Townsend, A. Neri, MD, oral communication, July 2013). CCC activities targeting the workplace include general adoption of worksite policies and provision of information about physical activity and nutrition. Some programs are seeking to expand existing prevention-related policies to reach more community members through the workplace setting; others are focused on specific worksites (eg, sun-safety at ski resorts, tobacco exposure in casinos). Identifying low-cost strategies and making them easily available may facilitate further adoption. CCC grantees also provide a strong network for information dissemination through their coalitions as new resources become available. 
NIOSH conducts research and develops programs to improve workplace conditions and practices to lower the incidence of occupationally related cancers. NIOSH focuses primarily on industrial sectors, occupations, and populations with elevated risk through basic bench research, on-site health hazard evaluations, recommendations for occupational exposure limits, timely health alerts, and training programs.

\section{CDC-Supported Resources}

Many CDC-supported workplace health promotion and protection resources are available (Table 2). For example, CDC provides guidance on smoke- and tobacco-free workplace policies that reduce tobacco use, initiation of tobacco use, and secondhand smoke exposure. Although not necessarily framed in the context of cancer prevention, many other CDC-supported resources address physical inactivity, diet and nutrition, and tobacco use, and some address cancer screening and early detection and weight management. Concerted efforts to share these resources with CCC programs and other funded partners may increase their dissemination and use at the state and local levels. Additionally, the CDC-supported Guide to Community Preventive Services provides evidence-based recommendations for worksite health promotion strategies (http://www.thecommunityguide.org/worksite/index.html). Continuing to link CCC grantees with relevant resources and expertise available in other parts of CDC may help maximize the impact of CDC's prevention work targeting adults.

\section{Conclusion}

The workplace is a key setting for efforts to reduce cancer risk among adults. Although some cancer risk factors have garnered attention in worksite health promotion, others have been somewhat overlooked and may be worth considering for future interventions. More could be done to take advantage of existing resources and prevention networks. Efforts to promote cancer prevention in the workplace may need to take an integrated and comprehensive approach by addressing individual behaviors, organizational culture, policies, and other environmental factors that influence cancer risk. We hope that the information and resources described in this essay will be useful to those working in health promotion and cancer prevention programs targeting adults.

\section{Acknowledgments}

Support for this essay was provided by CDC, Division of Cancer Prevention and Control. The findings and conclusions in this report are those of the authors and do not necessarily represent the official position of CDC. Members of the Cancer Prevention in the Workplace Writing Group (affiliations at time of contribution to the essay) are Pamela Allweiss, MD, MPH, Division of Diabetes Translation, CDC; David R. Brown, PhD, Division of Nutrition, Physical Activity, and Obesity, CDC; L. Casey Chosewood, MD, MPH, Total Worker Health Program, National Institute for Occupational Safety and Health, CDC; Joan M. Dorn, PhD, Division of Nutrition, Physical Activity, and Obesity, CDC; Shanta Dube, PhD, MPH, Office on Smoking and Health, CDC; Randy Elder, PhD, MEd, Division of Epidemiology, Analysis, and Library Services, CDC; Dawn M. Holman, MPH, Division of Cancer Prevention and Control, CDC; Heidi L. Hudson, MPH, Total Worker Health Program, National Institute for Occupational Safety and Health, CDC; C. Dexter Kimsey Jr, PhD, MSEH, Division of Nutrition, Physical Activity, and Obesity, CDC; Jason E. Lang, MPH, MS, Division of Population Health, CDC; Tina J. Lankford, MPH, Worklife Wellness Office, CDC; Chunyu Li, PhD, MD, MS, Division of Cancer Prevention and Control, CDC; Lisa Muirhead, DNP, APRN, ANP-BC, Nell Hodgson Woodruff School of Nursing, Emory University, Atlanta, Georgia; Antonio Neri, MD, MPH, Division of Cancer Prevention and Control, CDC; Marcus Plescia, MD, MPH, Division of Cancer Prevention and Control, CDC; Juan Rodriguez, MPH, Division of Cancer Prevention and Control, CDC; Anita L. Schill, PhD, MPH, MA, Total Worker Health Program, National Institute for Occupational Safety and Health, CDC; Meredith Shoemaker, MPH, Division of Cancer Prevention and Control, CDC; Glorian Sorensen, PhD, MPH, Center for Community-Based Research, Dana-Farber Cancer Institute, Boston, Massachusetts; Julie Townsend, MS, Division of Cancer Prevention and Control, CDC; Mary C. White, ScD, Division of Cancer Prevention and Control, CDC, Atlanta, Georgia.

\section{Author Information}

Corresponding Author: Dawn M. Holman, MPH, Division of Cancer Prevention and Control, Centers for Disease Control and Prevention, 4770 Buford Hwy, MS F76, Atlanta, GA 30341. Telephone: 770-488-4262. E-mail: dholman@cdc.gov.

\section{References}

1. Anderko L, Roffenbender JS, Goetzel RZ, Howard J, Millard F, Wildenhaus K, et al. Promoting prevention through the Affordable Care Act: workplace wellness. Prev Chronic Dis 2012;9:E175.

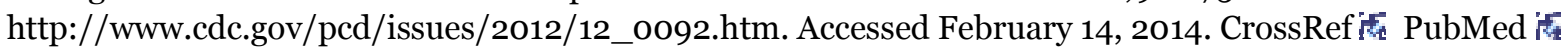


2. Sorensen G, Landsbergis P, Hammer L, Amick BC 3d, Linnan L, Yancey A, et al. Preventing chronic disease in the workplace: a workshop report and recommendations. Am J Public Health 2011;101(Suppl 1):S196-207. CrossRef 溚 PubMed 该

3. Frieden TR. A framework for public health action: the health impact pyramid. Am J Public Health 2010;100 (4):590-5. CrossRef it PubMed ita

4. Loeppke RR, Schill AL, Chosewood LC, Grosch JW, Allweiss P, Burton WN, et al. Advancing workplace health protection and promotion for an aging workforce. J Occup Environ Med 2013;55(5):500-6. CrossRef ít PubMed it

5. White MC, Holman DM, Boehm JE, Peipins LA, Grossman M, Henley SJ. Age and cancer risk: a potentially modifiable relationship. Am J Prev Med 2014;46(3 Suppl 1):S7-15. CrossRef ${ }^{-5}$ PubMed i

6. World Cancer Research Fund. Food, nutrition, physical activity, and the prevention of cancer: a global perspective. Washington (DC): American Institute for Cancer Research; 2007.

7. Centers for Disease Control and Prevention. Behavioral Risk Factor Surveillance System survey data. Atlanta (GA): US Department of Health and Human Services, Centers for Disease Control and Prevention; 2013. http://apps.nccd.cdc.gov/brfss/. Accessed April 30, 2014.

8. National Institute for Occupational Safety and Health. Asbestos fibers and other elongate mineral particles: state of the science and roadmap for research. Atlanta (GA): US Department of Health and Human Services, Centers for Disease Control and Prevention, 2011. http://www.cdc.gov/niosh/docs/2011-159/pdfs/2011-159.pdf. Accessed April 30, 2014.

9. Centers for Disease Control and Prevention. Malignant mesothelioma mortality - United States, 1999-2005. MMWR Morb Mortal Wkly Rep 2009;58(15):393-6. http://www.cdc.gov/mmwr/preview/mmwrhtml/mm5815a3.htm. Accessed June 12, 2014. PubMed it

10. Giovannucci E, Harlan DM, Archer MC, Bergenstal RM, Gapstur SM, Habel LA, et al. Diabetes and cancer: a consensus report. Diabetes Care 2010;33(7):1674-85. CrossRef if PubMed if

11. Centers for Disease Control and Prevention. 2011 National diabetes fact sheet. http://www.cdc.gov/diabetes/pubs/estimates11.htm. Accessed April 30, 2014.

12. Silverman DT, Samanic CM, Lubin JH, Blair AE, Stewart PA, Vermeulen R, et al. The Diesel Exhaust in Miners study: a nested case-control study of lung cancer and diesel exhaust. J Natl Cancer Inst 2012;104(11):855-68. CrossRefi度 PubMed iti

13. Ogden CL, Carroll MD, Kit BK, Flegal KM. Prevalence of obesity among adults: United States, 2011-2012. NCHS data brief, no. 131. Hyattsville (MD): National Center for Health Statistics; 2013.

14. El Ghissassi F, Baan R, Straif K, Grosse Y, Secretan B, Bouvard V, et al. A review of human carcinogens - Part D: radiation. Lancet Oncol 2009;10(8):751-2. CrossRef if PubMed if

15. President's Cancer Panel. Reducing environmental cancer risk: what we can do now. Bethesda (MD): US Department of Health and Human Services, National Institutes of Health, National Cancer Institute; 2010. http://deainfo.nci.nih.gov/advisory/pcp/annualReports/pcpo8-o9rpt/PCP_Report_08-09_508.pdf. Accessed April 30, 2014.

16. International Agency for Research on Cancer. Internalized $\alpha$-particle emitting radionuclides. 2012. http://monographs.iarc.fr/ENG/Monographs/vol10oD/mono10oD-9.pdf. Accessed April 30, 2014.

17. US Environmental Protection Agency. EPA's assessment of risks from radon in homes. 2013. http://www.epa.gov/radon/risk_assessment.html. Accessed April 30, 2014.

18. Wang Y, Beydoun MA. Meat consumption is associated with obesity and central obesity among US adults. Int $\mathrm{J}$

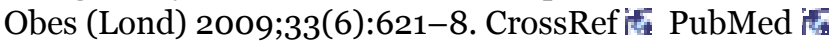

19. Lynch BM. Sedentary behavior and cancer: a systematic review of the literature and proposed biological mechanisms. Cancer Epidemiol Biomarkers Prev 2010;19(11):2691-709. CrossRef i PubMed i

20. Church TS, Thomas DM, Tudor-Locke C, Katzmarzyk PT, Earnest CP, Rodarte RQ, et al. Trends over 5 decades in U.S. occupation-related physical activity and their associations with obesity. PLoS ONE 2011;6(5):e19657. CrossRefiti PubMed if

21. International Agency for Research on Cancer. IARC monographs on the evaluation of carcinogenic risks to humans. Volume 98: painting, firefighting, and shiftwork. Lyon (FR); 2010. http://monographs.iarc.fr/ENG/Monographs/vol98/mono98.pdf. Accessed April 30, 2014.

22. Bureau of Labor Statistics. Workers on flexible and shift schedules in 2004 summary. 2005. http://www.bls.gov/news.release/flex.nro.htm. Accessed April 30, 2014. 
23. US Department of Health and Human Services. The health consequences of smoking -50 years of progress. A report of the Surgeon General. Atlanta (GA): Centers for Disease Control and Prevention, National Center for Chronic Disease Prevention and Health Promotion, Office on Smoking and Health; 2014.

24. Centers for Disease Control and Prevention. Current cigarette smoking prevalence among working adults United States, 2004-2010. MMWR Morb Mortal Wkly Rep 2011;60(38):1305-9.

http://www.cdc.gov/mmwr/preview/mmwrhtml/mm6038a2.htm. Accessed June 12, 2014. PubMed if

25. International Agency for Research on Cancer. IARC monographs on the evaluation of carcinogenic risks to humans. Volume 55: solar and ultraviolet radiation. Lyon (FR); 1997. http://monographs.iarc.fr/ENG/Monographs/vol55/volume55.pdf. Accessed April 30, 2014.

26. Holman DM, Berkowitz Z, Guy GP Jr, Hartman AM, Perna FM. The association between demographic and behavioral characteristics and sunburn among U.S. adults - National Health Interview Survey, 2010. Prev Med 2014;63:6-12. CrossRefi PubMed í

27. National Institute for Occupational Safety and Health. National Health Interview Survey: Occupational Health Supplement. http://www.cdc.gov/niosh/topics/nhis/healthcareoccsa/hcoccsafig13.html. Accessed April 30, 2014.

28. Krebs-Smith SM, Guenther PM, Subar AF, Kirkpatrick SI, Dodd KW. Americans do not meet federal dietary recommendations. J Nutr 2010;140(10):1832-8. CrossRefi PubMed i

29. Marriott BP, Olsho L, Hadden L, Connor P. Intake of added sugars and selected nutrients in the United States, National Health and Nutrition Examination Survey (NHANES) 2003-2006. Crit Rev Food Sci Nutr 2010;50 (3):228-58. CrossRef it PubMed it

30. Centers for Disease Control and Prevention. Adult participation in aerobic and muscle-strengthening physical activities - United States, 2011. MMWR Morb Mortal Wkly Rep 2013;62(17):326-30. http://www.cdc.gov/mmwr/preview/mmwrhtml/mm6217a2.htm. Accessed June 12, 2014. PubMed it

31. Database of state indoor air quality laws. Database excerpt: radon laws. Washington (DC): Environmental Law Institute; 2013. http://www.eli.org/buildings/database-state-indoor-air-quality-laws. Accessed April 30, 2014.

32. Alley DE, Chang VW. Metabolic syndrome and weight gain in adulthood. J Gerontol A Biol Sci Med Sci 2010;65

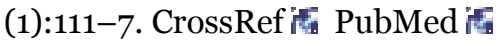

33. Pandalai SP, Schulte PA, Miller DB. Conceptual heuristic models of the interrelationships between obesity and the occupational environment. Scand J Work Environ Health 2013;39(3):221-32. CrossRef 活 PubMed i

34. Burgard SA, Lin KY. Bad jobs, bad health? How work and working conditions contribute to health disparities. Am Behav Sci 2013;57(8):1105-27. CrossRef it PubMed ith

35. Bunnell R, O’Neil D, Soler R, Payne R, Giles WH, Collins J, et al. Fifty communities putting prevention to work: accelerating chronic disease prevention through policy, systems and environmental change. $J$ Community Health 2012;37(5):1081-90. CrossRef i PubMed iक

36. McDonnell S, Bryant C, Harris J, Campbell MK, Lobb A, Hannon P, et al. The private partners of public health: public-private alliances for public good. Prev Chronic Dis 2009;6(2):A69. http://www.cdc.gov/pcd/issues/2009/apr/o8_0213.htm. Accessed April 21, 2014. PubMed î́

37. Gajendran RS, Harrison DA. The good, the bad, and the unknown about telecommuting: meta-analysis of psychological mediators and individual consequences. J Appl Psychol 2007;92(6):1524-41. CrossRef it:

38. Albelda R, Carr M. Low-wage and low-income workers in the U.S., 1979-2009. Boston (MA): Center for Social Policy; 2012.

\section{Tables}

Table 1. Examples of Cancer Risk Factors and Protective Factors That May Be Amenable to Workplace Interventionsa

\begin{tabular}{|c|c|c|}
\hline Factors & Associated Cancers & Prevalence Among US Adults \\
\hline \multicolumn{3}{|l|}{ Risk factors } \\
\hline $\begin{array}{l}\text { Alcohol } \\
\text { consumption }\end{array}$ & $\begin{array}{l}\text { Breast, colorectum, esophagus, larynx, } \\
\text { liver, oral cavity, pharynx (6) }\end{array}$ & $\begin{array}{l}\text { Approximately } 55 \% \text { of adults drink alcohol, } 17 \% \text { of } \\
\text { adults are binge drinkers, }{ }^{b} \text { and } 6 \% \text { are heavy } \\
\text { drinkers (7).c }\end{array}$ \\
\hline Asbestos & Larynx, lung, mesothelioma, ovary (8) & \\
\hline
\end{tabular}




\begin{tabular}{|c|c|c|}
\hline Factors & Associated Cancers & Prevalence Among US Adults \\
\hline & & $\begin{array}{l}\text { An estimated } 1.3 \text { million construction and general } \\
\text { industry workers are potentially exposed to asbestos } \\
\text { (9). }\end{array}$ \\
\hline Diabetes & $\begin{array}{l}\text { Bladder, breast, colon, endometrium, liver, } \\
\text { pancreas (10) }\end{array}$ & $\begin{array}{l}\text { Approximately } 11 \% \text { of adults have diabetes, and } \\
\text { prevalence increases with increasing age (11). }\end{array}$ \\
\hline Diesel exhaust & Lung (12) & $\begin{array}{l}\text { The amount of diesel exhaust adults are exposed to } \\
\text { varies greatly, but some of the highest levels of } \\
\text { exposure are among certain types of workers (eg, } \\
\text { truck drivers, miners). }{ }^{d}\end{array}$ \\
\hline Obesity & $\begin{array}{l}\text { Colorectum, endometrium, esophagus, } \\
\text { gallbladder, kidney, pancreas, } \\
\text { postmenopausal breast (6) }\end{array}$ & More than one-third of adults are obese (13). \\
\hline $\begin{array}{l}\text { Radiation exposure } \\
\text { from medical } \\
\text { imaging }\end{array}$ & Breast, leukemia, lung, thyroid (14) & $\begin{array}{l}\text { Americans receive nearly half their total radiation } \\
\text { exposure from medical imaging and other medical } \\
\text { sources (15). }\end{array}$ \\
\hline Radon & Lung (16) & $\begin{array}{l}\text { Approximately } 37 \% \text { of all radiation exposure is } \\
\text { attributed to radon, and there are an estimated } \\
21,000 \text { lung cancer deaths attributed to radon } \\
\text { exposure each year }(15,17) \text {. }\end{array}$ \\
\hline $\begin{array}{l}\text { Red meat } \\
\text { consumption }\end{array}$ & Colorectum (6) & $\begin{array}{l}\text { Adults consume an average of approximately } 40 \mathrm{~g} \text { of } \\
\text { red meat per day per person (18). }\end{array}$ \\
\hline $\begin{array}{l}\text { Sedentary } \\
\text { behavior }\end{array}$ & $\begin{array}{l}\text { Colorectum, endometrium, ovary, prostate } \\
(19)\end{array}$ & $\begin{array}{l}\text { Among employed adults, } 4 \text { out of } 5 \text { have } \\
\text { occupations that are sedentary or require only light } \\
\text { physical activity (20). }\end{array}$ \\
\hline Shift work & Breast $(21)$ & $\begin{array}{l}\text { Approximately } 15 \% \text { of full-time wage and salary } \\
\text { workers usually work a nonstandard shift (22). }\end{array}$ \\
\hline Tobacco use & $\begin{array}{l}\text { Acute myeloid leukemia, bladder, cervical, } \\
\text { colorectum, esophagus, kidney, larynx, } \\
\text { liver, lung, oral cavity, pancreas, pharynx, } \\
\text { stomach (23) }\end{array}$ & One in 5 working adults smokes cigarettes (24). \\
\hline $\begin{array}{l}\text { Ultraviolet } \\
\text { radiation exposure }\end{array}$ & $\begin{array}{l}\text { Skin (melanoma and nonmelanoma), } \\
\text { melanoma of the eye (25) }\end{array}$ & $\begin{array}{l}\text { Approximately } 37 \% \text { of adults experienced sunburn } \\
\text { in the past } 12 \text { months (26); among employed } \\
\text { adults, about } 1 \text { in } 4 \text { regularly works outdoors twice } \\
\text { per week or more (27). }\end{array}$ \\
\hline \multicolumn{3}{|l|}{ Protective Factors } \\
\hline Fruit consumption & $\begin{array}{l}\text { Esophagus, larynx, lung, pharynx, oral } \\
\text { cavity, stomach (6) }\end{array}$ & $\begin{array}{l}\text { Most adults do not meet federal dietary } \\
\text { recommendations for fruit intake (28). }\end{array}$ \\
\hline High-fiber diet & Colorectum (6) & $\begin{array}{l}\text { Less than } 5 \% \text { of adults meet or exceed adequate } \\
\text { intake levels for dietary fiber (29). }\end{array}$ \\
\hline Physical activity & $\begin{array}{l}\text { Colorectum, endometrium, postmenopausal } \\
\text { breast (6) }\end{array}$ & $\begin{array}{l}\text { Only } 1 \text { in } 5 \text { adults meets the } 2008 \text { Physical Activity } \\
\text { Guidelines for Americans ( } 30) \text {. }\end{array}$ \\
\hline $\begin{array}{l}\text { Radon testing and } \\
\text { mitigation }\end{array}$ & Lung (16) & $\begin{array}{l}\text { Only } 3 \text { states (Florida, New Hampshire, and Rhode } \\
\text { Island) require radon testing in all public buildings } \\
(31) \text {. }\end{array}$ \\
\hline $\begin{array}{l}\text { Vegetable } \\
\text { consumption }\end{array}$ & $\begin{array}{l}\text { Esophagus, larynx, stomach, oral cavity, } \\
\text { pharynx (6) }\end{array}$ & $\begin{array}{l}\text { Most adults do not meet federal dietary } \\
\text { recommendations for vegetable intake (28). }\end{array}$ \\
\hline $\begin{array}{l}\text { Weight } \\
\text { maintenance }\end{array}$ & Postmenopausal breast (6) & $\begin{array}{l}\text { Most adults experience clinically meaningful weight } \\
\text { gain ( } \geq 22 \text { pounds) during adulthood ( } 32) \text {. }\end{array}$ \\
\hline
\end{tabular}

a This list is not intended to be exhaustive but rather to provide examples of cancer risk-related factors that could be addressed in workplace health promotion and protection efforts.

b Binge drinkers are defined as men having 5 or more drinks on 1 occasion and women having 4 or more drinks on 1 occasion.

c Heavy drinkers are defined as men having more than 2 drinks per day or more than 14 drinks per week and women having more than 1 drink per day or more than 7 drinks per week. 
d The most recent estimates of occupational exposure are based on data from 1981-1983 and indicate that, at that time, approximately 1.35 million US workers were occupationally exposed to the combustion products of diesel fuel (http://www.cdc.gov/niosh/docs/88-116/\#niosh1983).

Table 2. Centers for Disease Control and Prevention (CDC) Resources Available to Promote Cancer Prevention in the Workplace

\section{Resource/Goal or Purpose}

Target Audience

Content

Cancer-Related Factors Addressed

Community Health Resources: Worksite Wellness, Community Health and Program Services Branch, http://apps.nccd.cdc.gov/dach_chaps/Default/LinksHealthTopic.aspx?topic $=26$

\begin{tabular}{l|l|l|l}
\hline $\begin{array}{l}\text { Assistance for community } \\
\text { health partners, coalitions, } \\
\text { and activists as they navigate } \\
\text { CDC's Web-based resources }\end{array}$ & $\begin{array}{l}\text { Employers, } \\
\text { employees, and } \\
\text { worksite health } \\
\text { promotion planners }\end{array}$ & $\begin{array}{l}\text { Searchable database; communications } \\
\text { and marketing campaigns; cross- } \\
\text { cutting programs; data and statistics; } \\
\text { guidelines and recommendations; } \\
\text { policy, partnership, and planning tools }\end{array}$ & $\begin{array}{l}\text { Tobacco use; diet } \\
\text { and nutrition; } \\
\text { physical activity; } \\
\text { weight } \\
\text { management; } \\
\text { screening and early } \\
\text { detection }\end{array}$ \\
\end{tabular}

Essential Elements of Effective Workplace Programs and Policies for Improving Worker Health and Wellbeing, National Institute for Occupational Safety and Health, http://www.cdc.gov/niosh/TWH/essentials.html

Guide for employers and employer-employee partnerships wishing to establish effective comprehensive work-based health protection and health promotion programs that sustain and improve worker health
Employers, employees, and worksite health promotion planners
Framework of 20 components categorized by organizational culture and leadership, program design, program implementation and resources, and program evaluation; guiding principles; practical direction
Tobacco use; diet and nutrition; physical activity; weight management

Healthier Worksite Initiative, Division of Nutrition, Physical Activity, and Obesity, http://www.cdc.gov/nccdphp/dnpao/hwi/index.htm

Comprehensive one-stop

-shop resource for workforce health promotion program planners
Worksite health promotion planners in state and federal government
Resources on a wide variety of workforce health promotion topics; program design tools and information about program planning and needs assessments; basic information about policies that affect health promotion at federal workplaces that also explains why they are important; resources and links to documents and websites with credible, useful information

Healthy Hospital Choices, Division of Nutrition, Physical Activity, and Obesity, http://www.cdc.gov/nccdphp/dnpao/hwi/docs/HealthyHospBkWeb.pdf

\section{Summary of meeting and} recommendations for action from expert panel on policy and environmental approaches to improve hospital worksite wellness

\section{Hospital employers,} hospital administrators, and public health practitioners
15 recommendations to improve the physical activity, nutrition, and tobaccofree environments of hospitals for their employees, patients, and visitors
Tobacco use; diet and nutrition; physical activity; weight management; screening and early detection

Investing in Health Guide, Partnership for Prevention in collaboration with CDC, http://www.prevent.org/WorksiteHealth/Investing-in-Health-Workplace-Guide.aspx

\begin{tabular}{|l|l|l|l|}
\hline $\begin{array}{l}\text { Guide to provide employers } \\
\text { with guidance that can } \\
\text { improve employee health }\end{array}$ & Employers & $\begin{array}{l}\text { Easy-to-follow action steps translated } \\
\text { from evidence-based recommendations } \\
\text { from the US Preventive Services Task }\end{array}$ & $\begin{array}{l}\text { Tobacco use; diet } \\
\text { and nutrition; } \\
\text { physical activity; } \\
\text { screening and early } \\
\text { detection }\end{array}$ \\
& $\begin{array}{l}\text { Force and the Task Force on } \\
\text { Community Preventive Services; guide } \\
\text { to help employers manage health care } \\
\text { spending and improve employee morale }\end{array}$ & \\
\hline
\end{tabular}




\begin{tabular}{|c|c|c|c|}
\hline Resource/Goal or Purpose & Target Audience & Content & $\begin{array}{l}\text { Cancer-Related } \\
\text { Factors Addressed }\end{array}$ \\
\hline \multicolumn{4}{|c|}{$\begin{array}{l}\text { Leading by Example, Partnership for Prevention in collaboration with CDC, } \\
\text { http://www.prevent.org/initiatives/leading-by-example.aspx }\end{array}$} \\
\hline $\begin{array}{l}\text { Peer-to-peer communication } \\
\text { campaign to educate chief } \\
\text { executive officers about the } \\
\text { benefits of worksite health } \\
\text { promotion and encourage } \\
\text { employers to adopt effective } \\
\text { practices to improve } \\
\text { employee health }\end{array}$ & $\begin{array}{l}\text { Chief executive } \\
\text { officers, upper-level } \\
\text { management, and } \\
\text { employers }\end{array}$ & $\begin{array}{l}\text { Publications to leverage the workplace } \\
\text { to improve health by promoting greater } \\
\text { business involvement in health } \\
\text { promotion and disease prevention; } \\
\text { publications to help chief executive } \\
\text { officers influence the American health } \\
\text { care system to emphasize prevention } \\
\text { rather than treatment }\end{array}$ & $\begin{array}{l}\text { Tobacco use; diet } \\
\text { and nutrition; } \\
\text { physical activity; } \\
\text { screening and early } \\
\text { detection }\end{array}$ \\
\hline \multicolumn{4}{|c|}{ Lean Works!, Division of Nutrition, Physical Activity, and Obesity, http://www.cdc.gov/leanworks/ } \\
\hline $\begin{array}{l}\text { Free Web-based resource to } \\
\text { help employers respond to the } \\
\text { obesity epidemic }\end{array}$ & $\begin{array}{l}\text { Employers and } \\
\text { worksite health } \\
\text { promotion planners }\end{array}$ & $\begin{array}{l}\text { Interactive tools; evidence-based } \\
\text { resources; obesity cost calculator }\end{array}$ & $\begin{array}{l}\text { Diet and nutrition; } \\
\text { physical activity; } \\
\text { weight management }\end{array}$ \\
\hline
\end{tabular}

National Healthy Worksite Program, Division of Population Health, http://www.cdc.gov/nationalhealthyworksite/index.html

\begin{tabular}{|l|l|l}
\hline $\begin{array}{l}\text { Program designed to assist } \\
\text { employers in implementing } \\
\text { science-based and practice- } \\
\text { based prevention and } \\
\begin{array}{l}\text { wellness strategies that will } \\
\text { lead to specific, measureable } \\
\text { health outcomes to reduce } \\
\text { chronic disease rates }\end{array}\end{array}$ & $\begin{array}{l}\text { Employers and } \\
\text { worksite health } \\
\text { promotion planners }\end{array}$ & $\begin{array}{l}\text { Stepwise approach to create or improve } \\
\text { a workplace health program; } \\
\text { comprehensive tool kit to support } \\
\text { training as well as supporting materials } \\
\text { and guidance for employers; } \\
\text { community and national training } \\
\text { opportunities; webinars and } \\
\text { teleconferences; on-going evaluation }\end{array}$ \\
\hline
\end{tabular}

Tobacco use; diet and nutrition; physical activity; weight management

Promising Practices for Total Worker Health (TWH), National Institute for Occupational Safety and Health, http://www.cdc.gov/niosh/TWH/practices.html

Quarterly feature in the electronic newsletter TWH in Action! to describe program design, frameworks, and implementation and to serve as a resource for understanding components of effective integrated safety and health programs
Employers, workers, human resource professionals, workplace safety and health professionals, and worksite health promotion professionals
Case examples that demonstrate characteristics of employer programs that aim to integrate health protection and health promotion
Tobacco use; diet and nutrition; physical activity; weight management; long work hours, fatigue, shift work, and healthy sleep

Save Lives, Save Money: Make Your Business Smoke-Free, Office on Smoking and Health, http://www.cdc.gov/tobacco/basic_information/secondhand_smoke/guides/business/

\begin{tabular}{|c|c|c|c|}
\hline $\begin{array}{l}\text { Brochure that provides } \\
\text { information on exposure to } \\
\text { secondhand smoke in the } \\
\text { workplace and the benefits to } \\
\text { employers once a smoke-free } \\
\text { workplace has been } \\
\text { implemented }\end{array}$ & Employers & Informational brochure & Tobacco use \\
\hline
\end{tabular}

School Employee Wellness: A Guide for Protecting the Assets of Our Nation's Schools, Directors of Health Promotion and Education in collaboration with CDC, http://www.healthyschoolsms.org/staff_health/documents/EntireGuide.pdf

\begin{tabular}{l|l|l|l}
$\begin{array}{l}\text { Comprehensive guide that } \\
\text { provides information, practical } \\
\text { tools, and resources for school } \\
\text { employee wellness programs }\end{array}$ & $\begin{array}{l}\text { School district policy } \\
\text { makers, school } \\
\text { administrators, and } \\
\text { employees }\end{array}$ & $\begin{array}{l}\text { Resources to promote the benefits of } \\
\text { school employee wellness programs; } \\
\text { model for establishing, implementing, } \\
\text { and sustaining a school employee } \\
\text { wellness program; practical tools and } \\
\text { resources to support the } \\
\text { implementation of school employee } \\
\text { wellness programs }\end{array}$ & $\begin{array}{l}\text { Tobacco use; diet } \\
\text { and nutrition; } \\
\text { physical activity; } \\
\text { weight } \\
\text { management; } \\
\text { screening and early } \\
\text { detection }\end{array}$ \\
\end{tabular}

Steps to Wellness, Division of Nutrition, Physical Activity, and Obesity, http://www.cdc.gov/nccdphp/dnpao/hwi/toolkits/pa-toolkit.htm 


\begin{tabular}{|l|l|l|l|}
\hline Resource/Goal or Purpose & \multicolumn{1}{|c|}{$\begin{array}{c}\text { Carget Audience } \\
\text { Tantent }\end{array}$} & $\begin{array}{l}\text { Cancer-Related } \\
\text { Factors Addressed }\end{array}$ \\
\hline $\begin{array}{l}\text { Guide to implementing the } \\
\text { Guidelines for Americans in } \\
\text { the Workplace, provides easy } \\
\text { and understandable steps on } \\
\text { how to increase the physical } \\
\text { activity of employees in the } \\
\text { workplace }\end{array}$ & $\begin{array}{l}\text { Employers and } \\
\text { worksite health } \\
\text { promotion planners }\end{array}$ & $\begin{array}{l}\text { A document explaining why businesses } \\
\text { should create a culture that values } \\
\text { physical activity for its employees; } \\
\text { steps to take to promote physical } \\
\text { activity and create a culture of wellness } \\
\text { in the workplace; tools and templates } \\
\text { to help businesses plan, promote, and } \\
\text { implement workplace physical } \\
\text { activities; additional resources about } \\
\text { physical activities and worksite wellness } \\
\text { programs }\end{array}$ & Physical activity \\
\hline
\end{tabular}

Swift Worksite Assessment and Translation, Division of Nutrition, Physical Activity, and Obesity, http://www.cdc.gov/nccdphp/dnpao/hwi/programdesign/swat.htm

\begin{tabular}{|l|l|l|l}
\hline $\begin{array}{l}\text { Evaluation method to rapidly } \\
\text { assess and identify promising } \\
\text { practices in workplace health } \\
\text { promotion programs }\end{array}$ & Employers & $\begin{array}{l}\text { Site identification and selection; 2-day } \\
\text { site visit; post-visit assessment of } \\
\text { promising practices; evaluation } \\
\text { capacity-building; translation and } \\
\text { dissemination }\end{array}$ & $\begin{array}{l}\text { Diet and nutrition; } \\
\text { physical activity; } \\
\text { weight management }\end{array}$ \\
\hline
\end{tabular}

Workplace Health Promotion Portal, Division of Population Health, http://www.cdc.gov/workplacehealthpromotion/

Online tool kit for active approaches to improving employee health

\begin{tabular}{l|l} 
Employers and & Wide variety of information, tools, \\
worksite health & $\begin{array}{l}\text { resources, and guidance for employers; } \\
\text { searchable database by topics of } \\
\text { interest; assessment, planning, } \\
\text { workplace governance, implementation, } \\
\text { and evaluation modules }\end{array}$
\end{tabular}

Employers and

Worksite Health ScoreCard, Division for Heart Disease and Stroke Prevention, http://www.cdc.gov/dhdsp/pubs/worksite_scorecard.htm

\begin{tabular}{|l|l|l|l|}
\hline $\begin{array}{l}\text { Tool to help employers assess } \\
\text { whether they have } \\
\text { implemented evidence-based } \\
\text { health promotion } \\
\text { interventions or strategies in } \\
\text { their worksites }\end{array}$ & $\begin{array}{l}\text { Employers and } \\
\text { worksite health } \\
\text { promotion planners }\end{array}$ & $\begin{array}{l}12 \text { topic sections; valid and reliable } \\
\text { assessment tool for comprehensive } \\
\text { health promotion and disease } \\
\text { prevention programs; identification of } \\
\text { program gaps and prioritization of high- } \\
\text { impact strategies }\end{array}$ & $\begin{array}{l}\text { Tobacco use; diet } \\
\text { and nutrition; } \\
\text { physical activity; } \\
\text { weight } \\
\text { management; } \\
\text { screening and early } \\
\text { detection }\end{array}$ \\
\hline
\end{tabular}

The opinions expressed by authors contributing to this journal do not necessarily reflect the opinions of the U.S. Department of Health and Human Services, the Public Health Service, the Centers for Disease Control and Prevention, or the authors' affiliated institutions.

For Questions About This Article Contact pcdeditor@cdc.gov

Page last reviewed: July 24, 2014

Page last updated: July 24, 2014

Content source: National Center for Chronic Disease Prevention and Health Promotion

Centers for Disease Control and Prevention 1600 Clifton Rd. Atlanta, GA 30333, USA

80o-CDC-INFO (800-232-4636) TTY: (888) 232-6348 - Contact CDC-INFO

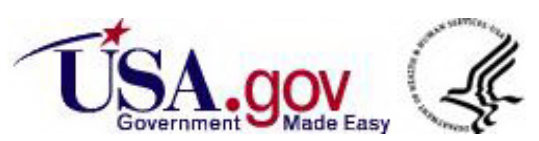

